\title{
The Canadian Ophthalmology Society's adaptation of the Medically Necessary Time-sensitive Surgical Procedures triage and prioritization tool
}

\author{
Salina Teja, MD \\ Colin Mann, MD \\ Phil Hooper, MD \\ Yvonne Buys, MD \\ Vivian T. Yin, MD, MPH
}

Accepted Aug. 12, 2020

\section{Correspondence to:}

V.T. Yin

Faculty of Medicine

University of British Columbia

2550 Willow St

Vancouver BC V5Z 3N9

viviany@me.com

DOI: $10.1503 /$ cjs. 012120

\begin{abstract}
SUMmarY
At the start of the coronavirus disease 2019 (COVID-19) pandemic, hospitals and ambulatory surgical centres significantly decreased elective surgical procedures to facilitate capacity for in-hospital beds, preserve personal protective equipment (PPE), preserve anesthetic medications and limit spread of infection. Non-COVID-19-related ophthalmic disease continues to affect vision, and it is anticipated that the backlog of elective surgeries will require months to years to resolve. The delivery of ophthalmic surgical care in a prioritized, systematic and transparent way is vital to manage the surgical back$\log$ while minimizing vision loss and consequent disability in the Canadian population. The Canadian Ophthalmology Society (COS) has modified the published Medically Necessary, Time Sensitive (MeNTS) Procedures scoring system to be applicable to all subspecialties within ophthalmology. This case prioritization process integrates medical necessity, consideration of resource preservation with risk of COVID-19 exposure, and factors unique to eye care. It provides guidance to Canadian ophthalmologists to facilitate decision making in triaging elective procedures.
\end{abstract}

\section{A} t the start of the coronavirus disease 2019 (COVID-19) pandemic, hospitals and ambulatory surgical centres significantly decreased elective surgical procedures in an effort to allow for in-patient bed capacity, preserve personal protective equipment (PPE), preserve anesthetic medications and limit the risk of spread of infection. Ophthalmology experienced one of the largest decreases in clinical and surgical volume, averaging at $-81 \%$ compared with an average across all service lines of $-54.5 \%$. $^{1}$ Two of the top 3 conditions that experienced the largest drop in encounters were cataracts $(-97 \%)$ and glaucoma $(-88 \%)$. Despite this reduction in patient encounters, non-COVID-19-related ophthalmic disease continues to affect vision, and it is anticipated that the backlog of elective surgeries required to treat these conditions will require months to years to resolve. These elective surgeries address visual impairment (VI) that affects patients' productivity, mental health, risk of falls, childhood development and quality of life. ${ }^{2}$ The effect of VI is not limited to the individual, but has a wider impact on patients' families and society as a whole. The delivery of ophthalmic surgical care in a prioritized, systematic and transparent way is vital to manage the surgical backlog while minimizing permanent vision loss and consequent disability in the Canadian population.

In the prepandemic era, clinical reasoning provided the construct for decision making between surgeons and patients to undergo elective surgery. Case prioritization at the hospital level integrated the surgeon's assessment of medical necessity and time sensitivity with available operating room (OR) resources. In the COVID-19 pandemic era, however, appropriate management of OR resources in the face of a large backlog of deferred surgical cases now demands a case prioritization process that integrates medical 
necessity with risk of COVID-19 exposure to both patients and the health care team as well as the use of health care resources like PPE, anesthetic medications and personnel. To this end, the Canadian Ophthalmology Society (COS) has adopted a framework originally published in the Fournal of the American College of Surgeons - the Medically Necessary, Time Sensitive (MeNTS) Procedures scoring system. ${ }^{3}$ The original validated tool was created through a review of the outcomes data regarding medical and perioperative outcomes of patients

Table 1. Ophthalmology prioritization framework*

\begin{tabular}{|c|c|c|c|c|c|c|}
\hline & Variable & 1 & 2 & 3 & 4 & 5 \\
\hline \multirow{4}{*}{ 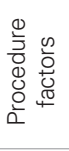 } & OR time, $\min$ & $<30$ & $30-60$ & $60-120$ & $120-180$ & $\geq 180$ \\
\hline & Surgical team size, $n$ & 1 & 2 & 3 & 4 & $>4$ \\
\hline & Estimated LOS & Outpatient & $<23 h$ & $24-48 h$ & $\leq 3 d$ & $>4 d$ \\
\hline & Need for GA & No & & & Yes & \\
\hline \multirow{7}{*}{ 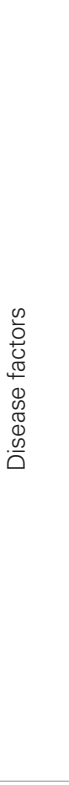 } & $\begin{array}{l}\text { Availability \& acceptability/ } \\
\text { effectiveness of nonsurgical } \\
\text { treatment option** }\end{array}$ & $\begin{array}{l}\text { None available } \\
\text { or high SE }\end{array}$ & $\begin{array}{c}\text { Available but } \\
<40 \% \text { as effective } \\
\text { as surgery or } \\
\text { moderate SE }\end{array}$ & $\begin{array}{l}\text { Available and } \\
40 \% \text { to } 60 \% \text { as } \\
\text { effective as } \\
\text { surgery }\end{array}$ & $\begin{array}{l}\text { Available and } 60 \% \\
\text { to } 95 \% \text { as } \\
\text { effective as } \\
\text { surgery, low risk } \\
\text { of SE }\end{array}$ & $\begin{array}{l}\text { Available and } \\
\text { equally effective }\end{array}$ \\
\hline & $\begin{array}{l}\text { Vision that falls below functional } \\
\text { needs** }\end{array}$ & $\begin{array}{l}\text { Monocular } \\
\text { patient }\end{array}$ & $\begin{array}{l}\text { Difficulty with ADLs } \\
\text { or significant impact } \\
\text { on development }\end{array}$ & $\begin{array}{l}\text { Below driving/ } \\
\text { occupati onal } \\
\text { requirements or } \\
\text { moderate impact } \\
\text { on development }\end{array}$ & $\begin{array}{l}\text { Approaching } \\
\text { driving/occupati } \\
\text { onal requirements } \\
\text { or minimal impact } \\
\text { on development }\end{array}$ & $\begin{array}{l}\text { No functional } \\
\text { limitation or } \\
\text { impact on } \\
\text { development }\end{array}$ \\
\hline & $\begin{array}{l}\text { Disease process causes } \\
\text { irreversible vision loss }\end{array}$ & $\begin{array}{l}\text { Never } \\
\text { reversible }\end{array}$ & $\begin{array}{l}\text { Partially reversible, } \\
\text { central-involving }\end{array}$ & $\begin{array}{l}\text { Partially } \\
\text { reversible, } \\
\text { non-central- } \\
\text { involving }\end{array}$ & & $\begin{array}{l}\text { Always } \\
\text { reversible }\end{array}$ \\
\hline & $\begin{array}{c}\text { Risk of significant vision loss or } \\
\text { progressive disease with 6-wk } \\
\text { delay }\end{array}$ & $\begin{array}{l}\text { Extremely } \\
\text { high }\end{array}$ & High & Moderate & Low & $\begin{array}{l}\text { Extremely low } \\
\text { or none }\end{array}$ \\
\hline & $\begin{array}{l}\text { Impact of 6-wk delay in increase } \\
\text { surgical difficulty, surgical risk, or } \\
\text { risk of additional intervention }\end{array}$ & $\begin{array}{l}\text { Significantly } \\
\text { worse }\end{array}$ & Worse & $\begin{array}{l}\text { Moderately } \\
\text { worse }\end{array}$ & Slightly worse & No worse \\
\hline & $\begin{array}{l}\text { COVID-19 exposure risk of } \\
\text { nonoperative treatment } \\
\text { compared with surgery** }\end{array}$ & $\begin{array}{l}\text { Not } \\
\text { applicable/ } \\
\text { significantly }\end{array}$ & Somewhat worse & Equivalent & Somewhat better & $\begin{array}{l}\text { Significantly } \\
\text { better }\end{array}$ \\
\hline & & worse & & & & \\
\hline \multirow{11}{*}{ 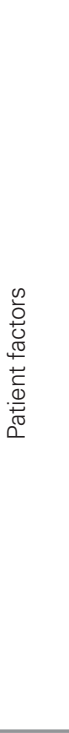 } & Age, yr & $<20$ & $20-50$ & $51-69$ & 70-79 & $\geq 80$ \\
\hline & Fall risk & High risk & Moderate risk & & Minimal risk & No fall risk \\
\hline & $\begin{array}{l}\text { Degree of pain or poor QOL (i.e., } \\
\text { diplopia) }\end{array}$ & $\begin{array}{l}\text { Extreme } \\
\text { distress or } \\
\text { discomfort }\end{array}$ & $\begin{array}{l}\text { Moderate distress or } \\
\text { discomfort }\end{array}$ & & $\begin{array}{l}\text { Low distress or } \\
\text { discomfort }\end{array}$ & $\begin{array}{l}\text { No distress or } \\
\text { discomfort }\end{array}$ \\
\hline & $\begin{array}{l}\text { Social factors complicating } \\
\text { care }^{* *}\end{array}$ & $\begin{array}{l}\text { Significant } \\
\text { social factors }\end{array}$ & Few social factors & & & No social factors \\
\hline & $\begin{array}{l}\text { Lung disease (asthma, COPD, } \\
\text { CF) }\end{array}$ & None & - & - & $\begin{array}{l}\text { Minimal (rare } \\
\text { inhaler) }\end{array}$ & > Minimal \\
\hline & Obstructive sleep apnea & Not present & - & - & $\begin{array}{l}\text { Mild/moderate } \\
\text { (no CPAP) }\end{array}$ & On CPAP \\
\hline & CV disease (HTN, CHF, CAD) & None & Minimal (no meds) & Mild ( $\leq 1$ med) & Moderate (2 meds) & $\begin{array}{c}\text { Severe ( } \geq 3 \\
\text { meds) }\end{array}$ \\
\hline & Diabetes & None & - & Mild (no meds) & $\begin{array}{l}\text { Moderate (PO } \\
\text { meds only) }\end{array}$ & $\begin{array}{l}>\text { Moderate } \\
\text { (insulin) }\end{array}$ \\
\hline & Immunocompromised & No & & & Moderate & Severe \\
\hline & $\begin{array}{c}\text { ILI symptoms (fever, cough, } \\
\text { sore throat, body aches, } \\
\text { diarrhea) }\end{array}$ & $\begin{array}{l}\text { None } \\
\text { (asymptom- } \\
\text { atic) }\end{array}$ & - & - & - & Yes \\
\hline & $\begin{array}{l}\text { Exposure to known COVID-19 } \\
\text { positive person in past } 14 \mathrm{~d}\end{array}$ & No & Probably not & Possibly & Probably & Yes \\
\hline \multicolumn{7}{|c|}{ 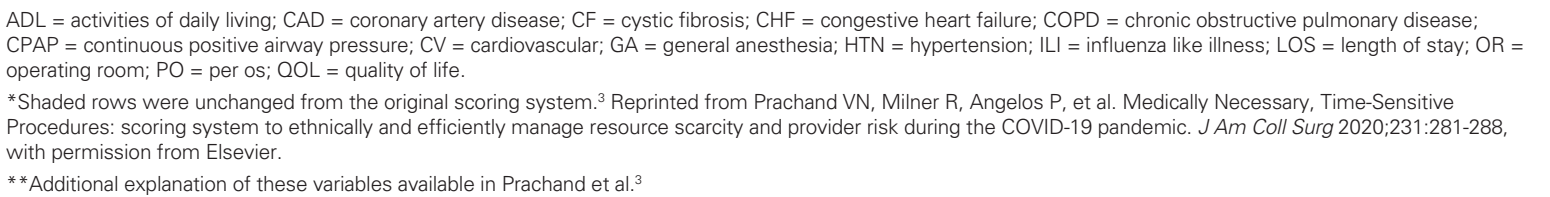 } \\
\hline
\end{tabular}


with COVID-19. We have modified this tool to be relevant and applicable to all subspecialties within ophthalmology while still preserving the factors that contribute to poorer outcomes, risk of virus transmission and demand on the health care system. The tool aligns with the 7 ethical principles of decision making - utility, fairness, equity, giving priority to the worst off, autonomy, minimizing harm and harmony ${ }^{2}$ - and provides standardized decision making both within and across institutions.

The adapted tool (Table 1) preserves the 3 categories of procedure, patient and disease factors, while maintaining the same number of questions, which allows for comparison among surgical specialties using the original MeNTS system. Thirteen of the questions were unchanged from the original MeNTS system and 8 were modified, as these were not relevant to ophthalmic surgery. Each question is graded on a 5-point scale, with higher numbers associated with increased risk of COVID-19 or less urgency; for example, a monocular patient would have higher priority and therefore a lower score.

Procedure factors take into consideration the sequestration of OR resources, exposure of patient and hospital personnel to COVID-19, and potential postoperative resources that could be required. Because many ophthalmic procedures are performed under topical or local anesthetic, the need for intubation for general anesthesia was incorporated as a key factor in decreasing priority based on risk associated with aerosolizing procedures.

Disease factors consider the impact on patient outcomes from delayed surgical care or nonoperative care being significantly less effective, not an option, or potentially resulting in increased risk of COVID-19 exposure to the patient; for example, increased number of in-person office visits. To tailor this to our specialty, we incorporated a factor to account for visual impairment that hinders the ability to function or childhood development. Other important considerations were to prioritize conditions that would cause irreversible vision loss if not operated on urgently, and risk for significant vision loss if surgery was delayed for at least 6 weeks.

Finally, patient factors consider conditions with known association of greater severity of COVID-19 illness, such as advanced age, lung and cardiovascular disease, and an immune-compromised state. This category captures instances in which there is a greater likelihood that the patient has COVID-19 when their infection status is not known. Our adaptation of the tool included the addition of a category for risk of falls due to vision impairment, as this causes substantial morbidity and strain on the patient and health care system in the long term. We also consider the impact of ophthalmic disease on the patient's quality of life and whether or not there are social factors that may complicate their care.

\section{Conclusion}

The COS has provided a framework for surgical case prioritization in the context of the COVID-19 pandemic that, in addition to medical necessity and risk for COVID19 transmission, systematically integrates factors that are unique to vision and eye care. This has provided guidance to Canadian ophthalmologists to facilitate decision making, triage for elective procedures and transparency in allocation of scarce OR resources.

Affiliations: From the Department of Ophthalmology and Visual Sciences, University of British Columbia, Vancouver, BC (Teja, Yin); the Department of Ophthalmology and Visual Sciences, Dalhousie University, Halifax, NS (Mann); the Department of Ophthalmology and Visual Sciences, University of Western Ontario (Hooper); and the Department of Ophthalmology and Visual Sciences, University of Toronto (Buys).

Competing interests: None declared.

Contributors: All authors contributed substantially to the conception, writing and revision of this article and approved the final version for publication.

Content licence: This is an Open Access article distributed in accordance with the terms of the Creative Commons Attribution (CC BYNC-ND 4.0) licence, which permits use, distribution and reproduction in any medium, provided that the original publication is properly cited, the use is noncommercial (i.e., research or educational use), and no modifications or adaptations are made. See: https://creativecommons. org/licenses/by-nc-nd/4.0/

\section{References}

1. Strata Decision Technology. National Patient and Procedure Volume Tracker. Version 5.11.2020.

2. Weih LM, Hassell JB, Keeffe J. Assessment of the impact of vision impairment. Invest Ophthalmol Vis Sci 2002;43:927-35.

3. Prachand VN, Milner R, Angelos P, et al. Medically Necessary, Time-Sensitive Procedures: scoring system to ethnically and efficiently manage resource scarcity and provider risk during the COVID-19 pandemic. 7 Am Coll Surg 2020;231:281-288. 